\title{
Analysis of Nonpoint Source Pollution and Water Environmental Quality Variation Trends in the Nansi Lake Basin from 2002 to 2012
}

\author{
Weiliang Wang, ${ }^{1}$ Tiantian Ju, ${ }^{1}$ Wenping Dong, ${ }^{2}$ Xiaohui Liu, ${ }^{1}$ Chuanxi Yang, \\ Yufan Wang, ${ }^{1}$ Lihui Huang, ${ }^{3}$ Zongming Ren, ${ }^{1}{ }^{2}$ Qi Qi, ${ }^{4}$ and Hongyan Wang ${ }^{5}$ \\ ${ }^{1}$ Shandong Normal University, Jinan 250014, China \\ ${ }^{2}$ Shandong Academy of Environmental Science and Environmental Engineering, Jinan 250013, China \\ ${ }^{3}$ Shandong Provincial Key Laboratory of Water Pollution Control and Resource Reuse, School of Environmental Science and \\ Engineering, Shandong University, Jinan 250100, China \\ ${ }^{4}$ Zoucheng No. 2 Middle School, Jinan 273500, China \\ ${ }^{5}$ Institute of Family Planning Science and Technology of Shandong Province, Jinan 250014, China
}

Correspondence should be addressed to Zongming Ren; zmren@sdnu.edu.cn

Received 20 January 2015; Accepted 6 May 2015

Academic Editor: Davide Vione

Copyright (C) 2015 Weiliang Wang et al. This is an open access article distributed under the Creative Commons Attribution License, which permits unrestricted use, distribution, and reproduction in any medium, provided the original work is properly cited.

\begin{abstract}
Based on the data analysis of economic development and the water environmental quality from 2002 to 2012 in the Nansi Lake Basin in China, the correlation between economic development and the water environmental quality was researched. Analysis shows that the GDP of the Nansi Lake Basin had an average annual growth of $7.3 \%$ in 2012, and the COD and COD $_{\mathrm{Mn}}$ had the average annual decrease of $7.69 \%$ and $6.79 \%$, respectively, compared to 2002. Basin water environmental quality overall improved, reaching Class III of the "Environmental quality standards for surface water (GB3838-2002)." The pollution of the water environment was analyzed from three aspects: agricultural fertilizers and pesticides, livestock, and aquaculture. Results indicated that the water pollution of the Nansi Lake Basin mainly came from nonpoint source pollution, accounting for more than $80 \%$ of the overall pollution. The contributions of both agricultural fertilizers and pesticides account for more than $85 \%$ of the overall nonpoint source, followed by livestock and aquaculture. According to the water pollution characteristics of the Nansi Lake Basin, the basin pollution treatment strategy and prevention and treatment system were dissected, to solve the pollution problem of the Nansi Lake Basin.
\end{abstract}

\section{Introduction}

Nonpoint source pollution has been put forth and confirmed since the 1980s. Its contribution to water pollution has been an increasing trend with point source pollution controlled effectively [1-4]. In recent years, the situation of lake pollution in our country worsened [5-7]. According to a survey of the Taihu Lake and Dianchi Lake [5, 8-10], nonpoint source pollution to water pollution contribution rate was over $70 \%$, which has become a major source of basin water pollution. The agricultural nonpoint source pollution is the most important part of nonpoint source pollution. It is estimated that the load of agricultural nonpoint source pollution is more than $50 \%$ of the total pollution, which makes an important contribution to basin water pollution $[8,11,12]$. Therefore, the agricultural nonpoint source pollution should be paid more concern and even more attention.

In the United States, although point source pollution has gradually been under control, the water quality has not improved since the 1960s. People have gradually realized the role of agricultural nonpoint pollution in basin water pollution is more important. Studies show that nonpoint source pollution accounts for about two-thirds of the total amount of pollution, in which agricultural nonpoint source pollution accounts for $68 \% \sim 83 \%$ [3, 13-15]. The agricultural nonpoint source pollution mainly includes the sources of farmland planting, livestock and aquaculture, rural life source, and other similar sources. There are a large number of pollutants, 
including nitrogen $(\mathrm{N})$ and phosphorus $(\mathrm{P})$ and other nutrients, organic pesticides, fertilizers, and other organic or inorganic pollutants, which cause the water environmental pollution by surface runoff and underground leakage $[16,17]$. With the characteristics of extensive, uncertain and longterm effects, the control of agricultural nonpoint source pollution is much more difficult than industrial pollution. Therefore, it is particularly urgent to conduct related research methods to control nonpoint source pollution $[18,19]$.

There are a large number of highly polluting industries including paper mills and chemical plants within the Nansi Lake Basin. When the eastern route of the South-To-North Water Diversion Project was first launched in 2002, water quality was inferior to Class $\mathrm{V}$ overall and COD in the local lake was upwards in the thousands of $\mathrm{mg} / \mathrm{L}$. The water pollution was so severe that common fish were unable to survive in the lake. According to the Chinese national plan for pollution treatment during the South-To-North Water Diversion Project, it is required to reduce over $80 \%$ of the pollutant discharge and control the COD emissions under $20 \mathrm{mg} / \mathrm{L}$, which was later remarked by experts as the Toughest Pollution Management Issue in the world [20]. Therefore, many scholars have been involved in the concern of the problem of the Nansi Lake Basin Water Pollution Control.

Based on the survey data of nonpoint source pollution in the Nansi Lake Basin, this paper focuses on the change trend and response relation between nonpoint source pollution and water environmental quality, since the implementation of the small watershed comprehensive pollution treatment strategy. Furthermore, the cause of the Nansi Lake Basin water environmental quality improvement was analyzed, with the aim to provide scientific basis and theoretical support for the treatment of nonpoint source pollution in Nansi Lake Basin.

\section{Background of the Nansi Lake Basin}

Nansi Lake $\left(34^{\circ} 27^{\prime} \mathrm{N}-35^{\circ} 20^{\prime} \mathrm{N}, 116^{\circ} 34^{\prime} \mathrm{E}-117^{\circ} 21^{\prime} \mathrm{E}\right)$, located in Shandong Province China, is the largest shallow freshwater lake in China, see Figure 1. It consists of four connected lakes, Nanyang Lake, Dushan Lake, Zhaoyang Lake, and Weishan Lake. The total surface water covers an area of $1,266 \mathrm{~km}^{2}$ but the average water depth is only $1.46 \mathrm{~m}$. The entire lake is in the administrative area of Weishan County, more than $70 \%$ of which is occupied by this lake $[21,22]$.

The water of the Nansi Lake Basin (Figure 1) mainly comes from three smaller cities located in Shandong Province, Zaozhuang, Jining, and Heze. These cities contain developing industries (paper, chemical, coal mining, operations, textile, etc.) which discharge harmful wastewater into the basin affecting water quality, vegetation, and wildlife from the surrounding $31,000 \mathrm{~km}^{2}$ watershed. As a buffer lake of the South-to-North Water Diversion Project (east route), the water quality should be better than Class III of the "China surface water quality standard (GB3838-2002)," according to the "Water Pollution Prevention Planning of the Southto-North Water Diversion Project (east route) of Shandong Section." It is important to note that pumping stations in the Nansi Lake will be used to control water storage and water

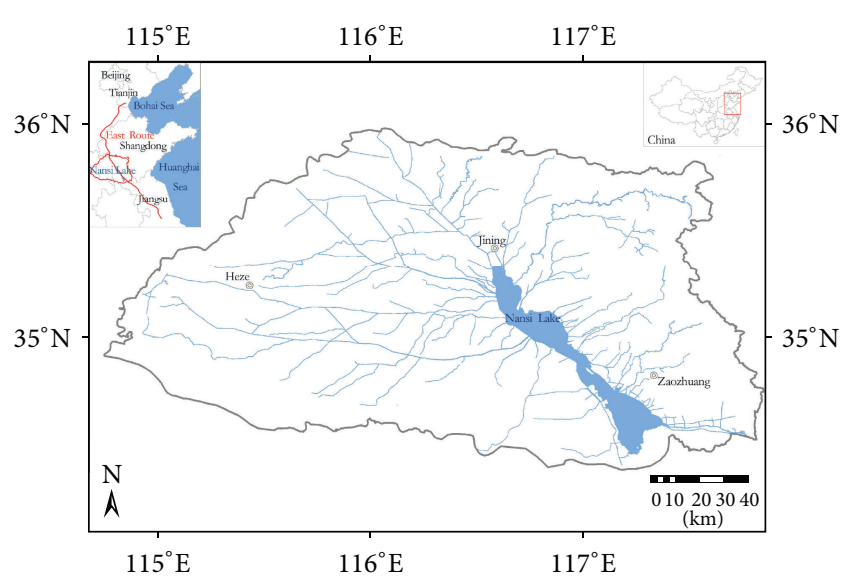

Figure 1: Nansi Lake Basin.

transfer in the East Route Project of Water Transfer from South-to-North in China.

After the building of a dam, the Nansi Lake was divided into two parts: the upper and lower lakes. The upper lakes have more inflow rivers compared to the lower lakes which include Nanyang Lake, Dushan Lake, and Zhaoyang Lake, covering an area of $2.75 \times 10^{4} \mathrm{~km}^{2}$ [21]. Under natural conditions, contaminations are carried and deposited by water from the upper lake to the lower lake and then go into canals. But after the water diversion project, the route of the water will be altered and the water will be sent through the pump station into the Liangji canal of the upper lakes from the lower lakes.

There are a total of 53 main rivers converging into Nansi Lake with no direct connection to the sea, including ten great inflow rivers, which drain an area of more than $1,000 \mathrm{~km}^{2}$. The average annual runoff amount into or out of the lake is $2.96 \times 10^{9} \mathrm{~m}^{3}$ and $1.92 \times 10^{9} \mathrm{~m}^{3}$, respectively. Furthermore, the area receives an annual average rainfall of $870 \mathrm{~mm}$. However, the rainfall is more concentrated in the summer months, accounting for 61 percent of the annual rainfall, and precipitation is lowest in winter $[22,23]$. Serving a population of approximately 19 million, it is a critical component of the east route, with all water via this route passing through it and then continuing on to one of the largest and most influential cities in China, Tianjin.

\section{The Change Trends of Economic Development and Water Environmental Quality in the Nansi Lake Basin}

3.1. Economic Development of the Nansi Lake Basin. The Nansi Lake Basin is one of the important economic areas of Shandong province. It is the most important freshwater fishery base, which is rich in aquatic resources and various aquatic animals and plants, such as fish, shrimp, lotus, and reed. Agriculture on the lakeside region is more developed; here wheat, corn, rice, soybeans, cotton, and other grain and oil crops are grown. There are also 34 different kinds of 


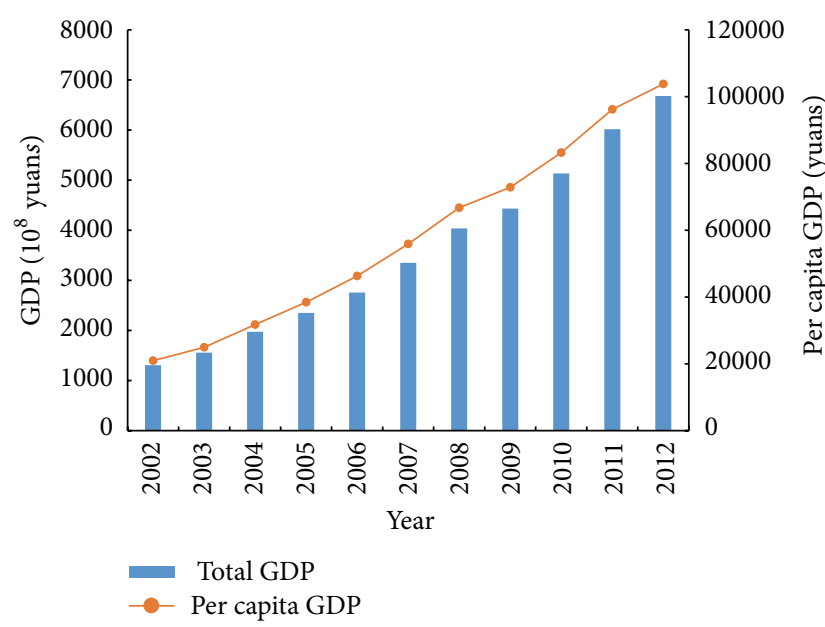

FIgURE 2: The total GDP and per capita GDP in the Nansi Lake Basin during 2002 2012.

industrial projects including papermaking, chemical plant, and coal mining within the region.

With the economic development of the Nansi Lake Basin improving continuously, the gross domestic product (GDP) shows a trend of sustained growth for the last 10 years, especially since the "Eleventh Five-Year Plan." From 2002 to 2012, the economy of the Nansi Lake Basin has been in a rapid developmental period. The total GDP has increased from 130.74 billion yuans to 667.98 billion yuans, with an increase of 5.1 times and an average annual growth rate of $7.3 \%$. In addition, the per capita GDP has also increased from $2.09 \times$ $10^{4}$ yuans to $1.04 \times 10^{5}$ yuans (Figure 2).

During the period from 2002 to 2012, the added value of primary industry, secondary industry, and tertiary industry in the Nansi Lake Basin was growing. The proportion of three industries had been adjusted from $21.29: 44.48: 34.23$ in 2002 to $10.89: 53.12: 35.99$ in 2012 (Figure 3). As can be observed in Figure 4, the proportion of primary industry has continued to decline. The secondary industry showed a trend of rising before a small decrease, and the proportion achieved the maximum in 2008 , of $56.60 \%$. The proportion of tertiary industry is still increasing from 2005, but the overall changes are quite gentle. In summary, the proportion of secondary industry is still larger, and tertiary industry is still relatively small. However, one can see that irrational proportion of the three industries directly causes an increase in water pollution.

For the primary industry, agriculture and animal husbandry have been the outstanding industries in the Nansi Lake Basin and have still developed rapidly in recent years. During 2002 to 2012, the primary industrial GDP increased from 49.20 billion yuans to 141.90 billion yuans, which was an increase of about three times. In 2012, agricultural GDP reached 84.84 billion yuans, accounting for $59.78 \%$ of the primary industry GDP. Animal husbandry (30.19\%) in the GDP reached 42.84 billion yuans and then followed by forestry $(1.46 \%)$ and fishery (5.06\%), whose development has been slow over the years (as shown in Table 1).

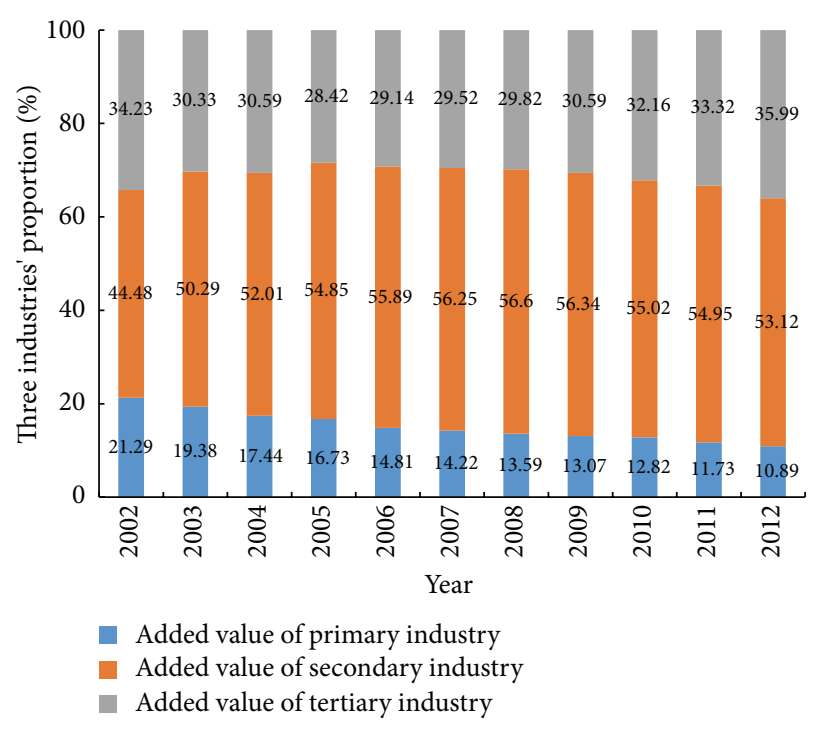

FIgURE 3: Three industries' structure in the Nansi Lake Basin during 2002 2012.

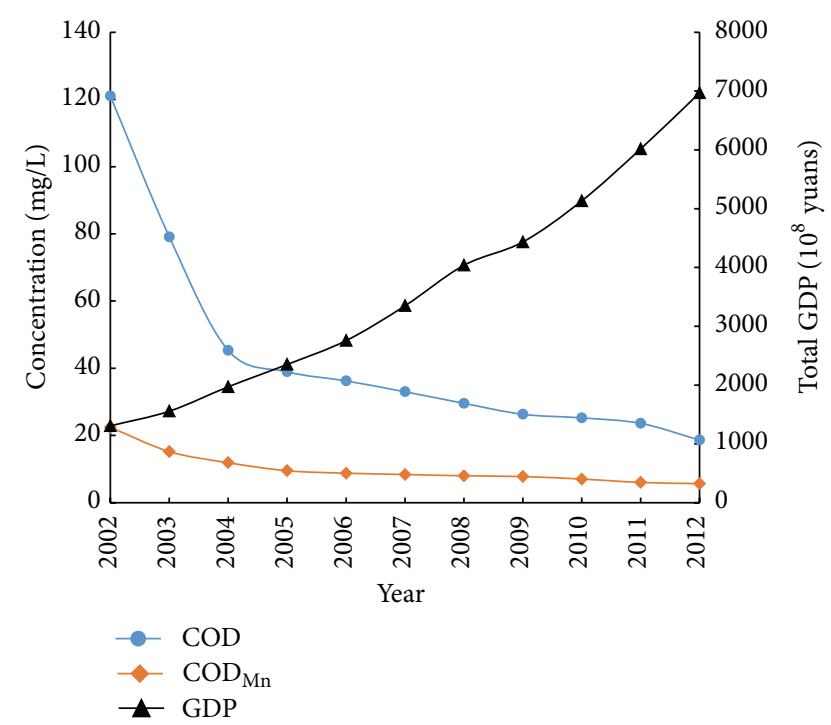

FIGURE 4: The variation trends of water quality with GDP growth in the Nansi Lake Basin during 2002 2012.

3.2. Analysis of Economic Development and Water Environmental Quality Variation Relationship in the Nansi Lake Basin. In the Nansi Lake Basin, the characteristics of topography, geomorphology, and land use are complicated, and in addition the pollution sources such as industry, agriculture, and city life are dotted. All kinds of pollutants enter into the Nansi Lake through the rivers, which poses a threat to the basin water environment. According to water pollution situations and management needs of the Nansi Lake Basin, the monitoring data of water quality indicators (COD and $\mathrm{COD}_{\mathrm{Mn}}$ ) was analyzed to assess the water environmental quality variation in the Nansi Lake Basin. Water quality data were monitored in the middle of the Nansi Lake Basin every month from 2002 to 2012 by Shandong Academy of 
TABLE 1: The basic situation of primary industry in the Nansi Lake Basin from 2002 to 2012.

\begin{tabular}{cccccccccc}
\hline & Primary industry & \multicolumn{2}{c}{ Agriculture } & \multicolumn{2}{c}{ Forestry } & \multicolumn{2}{c}{ Animal husbandry } & \multicolumn{2}{c}{ Fishery } \\
Year & $\begin{array}{c}\text { GDP } \\
\text { GD }\end{array}$ & $\begin{array}{c}\text { GDP } \\
\left(10^{8} \text { yuans }\right)\end{array}$ & $\begin{array}{c}\text { Proportion } \\
\left(10^{8} \text { yuans }\right)\end{array}$ & $\begin{array}{c}\text { GDP } \\
(\%)\end{array}$ & $\begin{array}{c}\text { Proportion } \\
\left(10^{8} \text { yuans }\right)\end{array}$ & $\begin{array}{c}\text { GDP } \\
(\%)\end{array}$ & $\begin{array}{c}\text { Proportion } \\
\left(10^{8} \text { yuans }\right)\end{array}$ & $\begin{array}{c}\text { GDP } \\
(\%)\end{array}$ & $\begin{array}{c}\text { Proportion } \\
\left(10^{8} \text { yuans }\right)\end{array}$ \\
\hline 2002 & 492.08 & 319.80 & 64.99 & 12.28 & 2.50 & 137.33 & 27.91 & 22.67 \\
2003 & 527.33 & 321.85 & 61.03 & 13.46 & 2.55 & 163.17 & 30.94 & 22.69 & 4.61 \\
2004 & 644.75 & 380.44 & 59.01 & 14.87 & 2.31 & 205.61 & 31.89 & 29.65 & 4.60 \\
2005 & 739.94 & 439.85 & 59.44 & 13.64 & 1.84 & 238.4 & 32.22 & 32.32 & 4.37 \\
2006 & 794.21 & 481.80 & 60.66 & 16.75 & 2.11 & 228.02 & 28.71 & 37.47 & 4.72 \\
2007 & 896.25 & 529.16 & 59.04 & 18.19 & 2.03 & 280.19 & 31.26 & 40.23 & 4.49 \\
2008 & 1041.71 & 639.76 & 61.41 & 19.68 & 1.89 & 307.71 & 29.54 & 41.71 & 4.00 \\
2009 & 1090.30 & 674.42 & 61.86 & 18.17 & 1.67 & 311.44 & 28.56 & 49.35 & 4.53 \\
2010 & 1237.17 & 775.96 & 62.72 & 17.60 & 1.42 & 346.05 & 27.97 & 56.66 & 4.58 \\
2011 & 1342.66 & 803.68 & 59.86 & 19.16 & 1.43 & 410.53 & 30.58 & 63.74 \\
2012 & 1418.89 & 848.23 & 59.78 & 20.72 & 1.46 & 428.35 & 30.19 & 71.77 \\
\hline
\end{tabular}

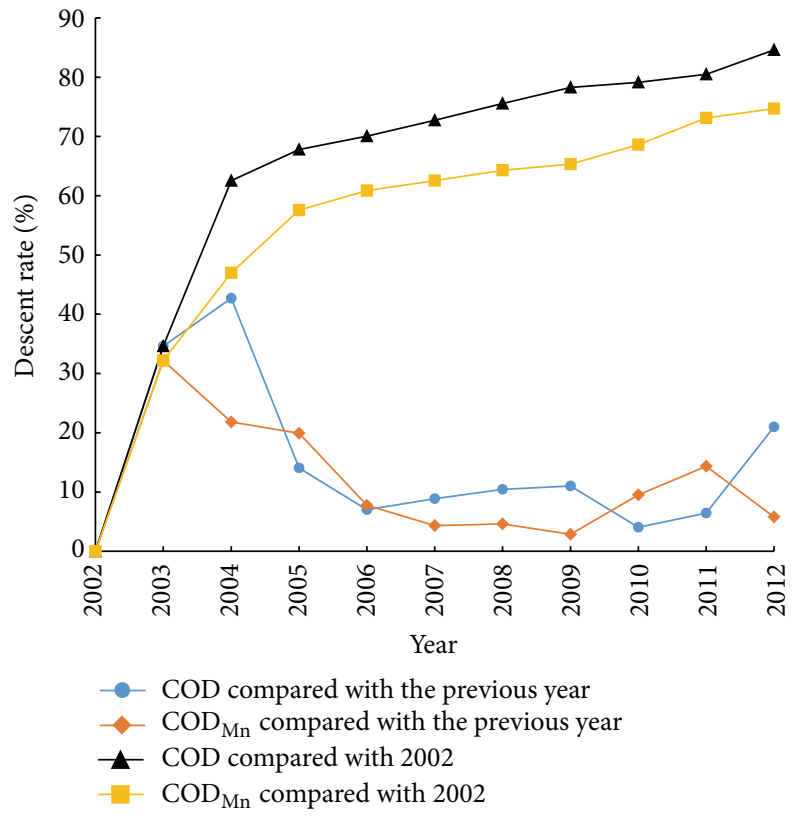

FIgURE 5: The descent rate of pollutants concentration in the Nansi Lake Basin during 2002 2012.

Environmental Science and Environmental Engineering, and then the average values were used to show the water quality of each year.

Through the development and improvement of the “TREATMENT, RECYCLING and RESTORATION" basin pollution management system, the Nansi Lake has managed to improve its water quality at a double-digit annual growth, while maintaining double-digit GDP annual growth during the period from 2002 to 2012. According to the COD and $\mathrm{COD}_{\mathrm{Mn}}$ concentration of the water quality in the Nansi Lake Basin for the last 10 years, the change of annual averages, and the descent rate of water quality indicators were analyzed, alongside a double-digit GDP annual growth within region (as shown in Figures 4 and 5).
As can be seen from Figure 4, the concentration of COD and $\mathrm{COD}_{\mathrm{Mn}}$ in the Nansi Lake Basin appears to be in an overall descent trend from 2002 to 2012, but the extent of the decline varies each year. Because of major pollution discharging points and entrances into main streams and lakes, agricultural nonpoint source pollution increasing, and livestock and aquaculture pollution aggravating, the COD concentration has begun to decrease slowly since 2004. In 2009, the average concentrations of COD and $\mathrm{COD}_{\mathrm{Mn}}$ in the Nansi Lake Basin were $26.31 \mathrm{mg} / \mathrm{L}$ and $7.78 \mathrm{mg} / \mathrm{L}$, respectively. At this point, water quality only reached a Class IV overall. Compared to 2002, where the overall descent rates of COD and $\mathrm{COD}_{\mathrm{Mn}}$ were above $65 \%$, the water environmental quality of the Nansi Lake Basin has improved greatly. With the degree of pollution control in the Nansi Lake Basin increasing and highly polluting industries transformed or closed, the concentration of COD and $\mathrm{COD}_{\mathrm{Mn}}$ reached $18.65 \mathrm{mg} / \mathrm{L}$ and $5.68 \mathrm{mg} / \mathrm{L}$, and the overall descent rate reached, respectively, $84.59 \%$ and $74.68 \%$ in 2012 . In addition, the water quality basically reached a Class III water standard.

We can see from Figure 5 that the overall descent rate of COD appeared to have a larger value in 2004, while the $\mathrm{COD}_{\mathrm{Mn}}$ showed a larger value in 2003. There are a large number of reasons involved in this phenomenon, to name a few, the "TREATMENT, RECYCLING and RESTORATION" basin pollution management system implemented in 2002, "Effluent standards of water pollutants for paper industry" (DB37/336-2003) carried out in 2003, and the sewage treatment plants put into operation in the Nansi Lake Basin in 2004. Furthermore, "Effluent standards of water pollutants in South-To-North Water Diversion Project" (DB37/599-2006) was carried out in 2006. In order to further control the water pollution for basically improving the water environment quality and keep sustained and rapid economic development at the same time in the Nansi lake basin, the environmental protection departments and the enterprises had been strictly implementing the scientific standards, according to the “TREATMENT, RECYCLING and RESTORATION" basin pollution management system. 
3.3. Analysis on the Pollution Contribution of Nonpoint Source Related Industries in the Nansi Lake Basin. Through the analysis of economic development and industrial structure in the Nansi Lake Basin during the period from 2002 to 2012, and combining it with the pollution characteristics of other basin's water environment $[5,9,11,24]$, we can see with the continuous growth of GDP in the Nansi Lake Basin, the water environmental pollution of the basin has been increasingly more and more serious, including the nonpoint source pollution and point source pollution (Table 2). Nonpoint source is the main pollution source, including agricultural pesticides and fertilizers pollution, contamination of livestock, and aquaculture pollution. In particular, the pollution of forestry, even though it accounts for a small proportion, is still negligible.

The loss of agricultural runoff pollutants equals crop planting area multiplied by farmland runoff pollutants loss coefficient; aquaculture pollution emissions equal aquaculture production multiplied by pollutant discharge coefficient. Point source pollution emissions are calculated by urban domestic sewage emissions plus industrial waste emissions [25]. And the calculating formula on the loss of Livestock and poultry breeding pollutants is as follows:

$$
\begin{aligned}
& X=A * B * 10^{-3} C, \\
& Y=a * B * 10^{-3} C, \\
& Z=X * 10^{-3} D+Y * 10^{-3} E .
\end{aligned}
$$

$X$ is annual dung emissions ( $\mathrm{t} / \mathrm{a}), Y$ is annual urine emissions (t/a), $A$ is individual daily output of dung $(\mathrm{kg} /(\mathrm{d} \cdot \mathrm{head}))$, $a$ is individual daily output of urine $(\mathrm{kg} /(\mathrm{d} \cdot \mathrm{head})), B$ is feeding cycle (d), $C$ is the amount of breeding, $D$ is the average content of dung pollutants $(\mathrm{kg} / \mathrm{t}), E$ is the average content of urine pollutants $(\mathrm{kg} / \mathrm{t})$, and $Z$ is annual pollutant emissions $(\mathrm{t} / \mathrm{a})$. Furthermore, the loss of pollutants is calculated by $12 \%$ of emissions, and the specific coefficients are shown in Table 3 $[26,27]$.

As can be seen from Table 2, the contribution of nonpoint source pollution is greater than point source pollution in the Nansi Lake Basin water environment; these accounts for the proportion of more than $85 \%$. The COD pollution of the basin water environment is mainly from agricultural nonpoint source pollution and livestock and poultry industry pollution, while the $\mathrm{NH}_{3}-\mathrm{N}$ pollution is mainly from aquaculture.

The nonpoint source pollution is increasing yearly. In 2009 , the contribution percentage of $\mathrm{COD}$ and $\mathrm{NH}_{3}-\mathrm{N}$ from nonpoint source pollution reached $87.96 \%$ and $93.21 \%$, respectively. The contribution from agricultural fertilizer and pesticide is the largest, accounting for $91.68 \%$ and $86.05 \%$ overall, followed by livestock and poultry breeding, aquaculture. Comparing this to the agriculture, their contribution is very small. But the pollution from livestock and aquaculture to the water environment cannot be ignored, because the control of pollution is long-term and the pollution sources are disperse. Through the comprehensive analysis of emissions from various industries, it is easy to surmise that the water

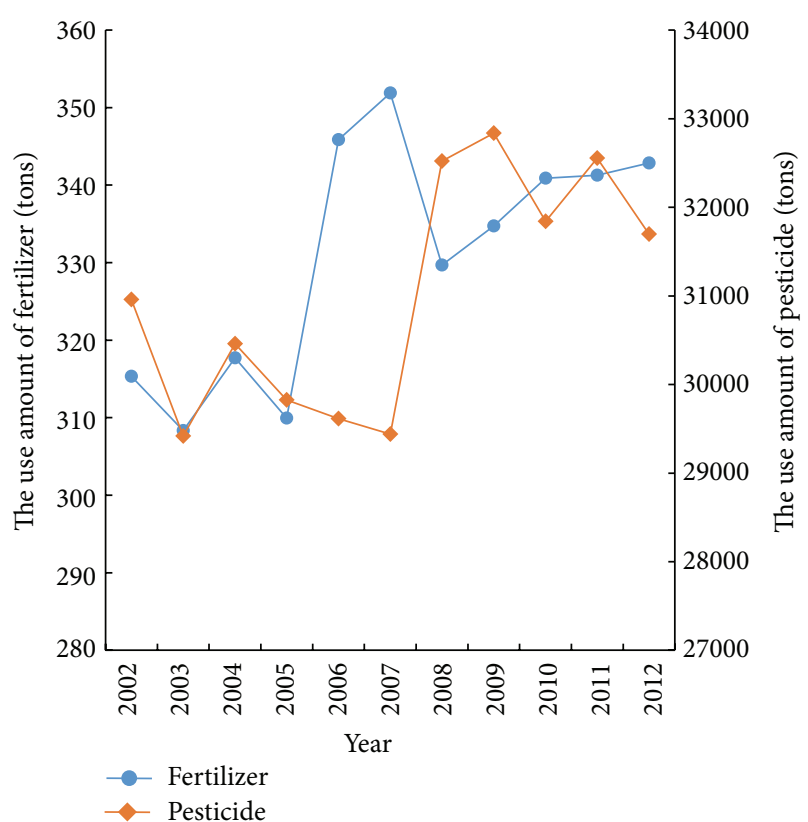

FIgURE 6: The amount changes of fertilizer and pesticide in the Nansi Lake Basin during 2002 to 2012.

environmental pollution of the Nansi Lake Basin is mainly caused by agricultural nonpoint source pollution.

3.3.1. Pollution of Agricultural Fertilizer and Pesticide. During 2002 to 2012, the changes of the amount of fertilizers and pesticides in the Nansi Lake Basin are shown in Figure 6. It can be seen that the amount shows an increasing trend, but the amount of fertilizers and pesticides appears to largely fluctuate in 2006 and 2008, which may be caused by the crop species, types of fertilizers, and pesticides and government policies. An example of government policies would be the "control planning of agricultural nonpoint source pollution in the South-To-North Water Diversion Project" and the "action plan of two aspects' reduction and three aspects' protection in basin agriculture."

As for the use of fertilizer, nitrogenous fertilizer accounts for a larger proportion overall, which is about $40 \%$, whereas the amount of phosphate fertilizer is decreasing continuously. In 2008 , that amount was about $6.95 \times 10^{5}$ tons, which decreased $8.1 \%$ compared to 2007 . The amount change of potassium fertilizer shows a gentle trend, and average annual amount is $2.70 \times 10^{5}$ tons. Furthermore, in recent years, the amount of compound fertilizer continued to grow, with an average annual growth of $4.3 \%$, which reached $1.14 \times 10^{5}$ tons in 2012.

Presently, in our country, the average utilization rate of nitrogenous fertilizer and phosphate fertilizer is 30\% 35\% and $10 \% \sim 20 \%,[28,29]$ with the arable land of the Nansi Lake Basin in Shandong province being $1.67 \times 10^{4} \mathrm{~km}^{2}$. However, the amount of fertilizers and pesticides reached, respectively, 3.35 million tons and $3.28 \times 10^{4}$ tons in 2009; this includes nitrogenous fertilizer at 1.34 million tons, phosphate fertilizer at $6.85 \times 10^{5}$ tons, and potassium fertilizer at $2.74 \times 10^{4}$ tons. 


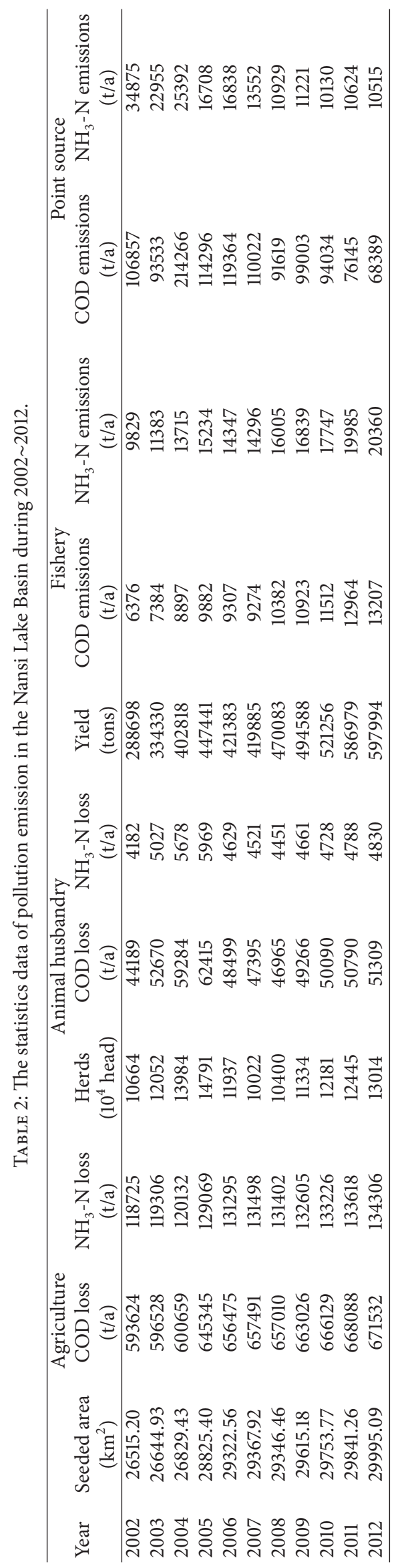


TABLE 3: The fecal excretion coefficient and the average content of pollutants.

\begin{tabular}{|c|c|c|c|c|c|c|c|}
\hline & \multirow{2}{*}{$\begin{array}{l}\text { Dung emissions } \\
(\mathrm{kg} / \mathrm{d})\end{array}$} & \multirow{2}{*}{$\begin{array}{l}\text { Urine emissions } \\
\qquad(\mathrm{kg} / \mathrm{d})\end{array}$} & \multirow{2}{*}{$\begin{array}{c}\text { Feeding cycle } \\
\text { (d) }\end{array}$} & \multicolumn{2}{|c|}{$\mathrm{COD}_{\mathrm{Cr}}(\mathrm{kg} / \mathrm{t})$} & \multicolumn{2}{|c|}{$\mathrm{NH}_{3}-\mathrm{N}(\mathrm{kg} / \mathrm{t})$} \\
\hline & & & & Dung & Urine & Dung & Urine \\
\hline Cow & 20 & 10 & 365 & 31 & 6 & 1.7 & 3.5 \\
\hline Pig & 2 & 3.3 & 150 & 52 & 9 & 3.1 & 1.4 \\
\hline Chicken & 0.1 & - & 60 & 45 & - & 4.8 & - \\
\hline
\end{tabular}

TABLE 4: The situation of livestock and poultry breeding industry in the Nansi Lake Basin.

\begin{tabular}{|c|c|c|c|c|}
\hline \multirow{2}{*}{ The survey project } & \multicolumn{3}{|c|}{ The species of livestock and poultry breeding } & \multirow{2}{*}{ Total } \\
\hline & Cattle & Pig & Chicken & \\
\hline Herds ( $10^{4}$ heads) & 95.79 & 720.01 & 10517.87 & 11333.67 \\
\hline Annual dung emissions (tons) & 6992670 & 2160030 & 631072 & 9783772 \\
\hline Annual urine emissions (tons) & 3496335 & 3564050 & - & 7060385 \\
\hline \multicolumn{5}{|c|}{ Annual pollutants productions (tons) } \\
\hline COD & 237751 & 144398 & 28398 & 410547 \\
\hline $\mathrm{NH}_{3}-\mathrm{N}$ & 24125 & 11686 & 3029 & 38840 \\
\hline \multicolumn{5}{|l|}{ Annual loss of pollutants (tons) } \\
\hline $\mathrm{COD}$ & 28530 & 17328 & 3408 & 49266 \\
\hline $\mathrm{NH}_{3}-\mathrm{N}$ & 2895 & 1402 & 364 & 4661 \\
\hline
\end{tabular}

The total fertilization strength after pure discount was more than $6.77 \times 10^{4} \mathrm{~kg} / \mathrm{km}^{2}$, which was about 1.65 times of the national standard $\left(4.11 \times 10^{4} \mathrm{~kg} / \mathrm{km}^{2}\right)$, and the strength of pesticide was $1963 \mathrm{~kg} / \mathrm{km}^{2}$, which was 1.75 times of national standard $\left(1,125 \mathrm{~kg} / \mathrm{km}^{2}\right)[30]$.

Extensive use of fertilizer and pesticide, as well as unreasonable proportions $(\mathrm{N}: \mathrm{P}: \mathrm{K}$ is about $1: 0.51: 0.21)$, increases the loss of fertilizers and pesticides, so that the pollution of the Nansi Lake Basin water environment becomes more and more serious [31]. According to the change of farmland fertilizer amount and annual rainfall, the loss correction coefficient of farmland runoff pollutants is selected as $1.5[6,25]$, so the loss coefficient of farmland runoff pollutants of COD and $\mathrm{NH}_{3}-\mathrm{N}$ is $1.49 \times 10^{4} \mathrm{~kg} / \mathrm{km} \cdot$ Year and $2,985.07 \mathrm{~kg} / \mathrm{km}^{2}$. Year, respectively. In 2009, the basin water environmental pollution caused by $\mathrm{COD}$ and $\mathrm{NH}_{3}-\mathrm{N}$ reached, respectively, $91.68 \%$ and $86.05 \%$. A large number of $\mathrm{N}$ and $\mathrm{P}$ flowed into the water body resulting in the eutrophication of the basin water environment [32].

3.3.2. Pollution of Livestock and Poultry Industry. With the number of livestock and poultry breeding increasing and utilizing scale amplification, the pollution of livestock and poultry industry is increasingly highlighted. In agriculture, fertilizers replace the farmyard manure, resulting in a reduced demand for livestock and poultry manure. On the other hand, the utilization rate and the treatment rate of livestock and poultry manure are very low. Thus some pollutants produced by livestock and poultry breeding have become one of the main sources of agricultural nonpoint source pollution.

Over the past decade, with the rapid development of the livestock and poultry breeding industry in the Nansi Lake Basin, the pollutants discharge has shown a trend of "increase-decreases-increased," which increase the water environmental bearing capacity of the Nansi Lake Basin. The data consisting of dung produced by cattle, pigs, and chickens was analyzed to understand the pollution of livestock and poultry breeding in the Nansi Lake Basin. Table 4 shows the situation of the livestock and poultry breeding industry of the Nansi Lake Basin for 2009.

From Table 4, it can be seen that herds of cattle, pigs, and chickens are $9.58 \times 10^{5}, 7.2 \times 10^{6}$, and $1.05 \times 10^{8}$ which increases $2.83 \%, 6.97 \%$, and $2.83 \%$, respectively, compared to 2008. Due to the fact that there is almost no sewage treatment facility in the study area, the pollutant generating coefficients of livestock was estimated as those of scattered livestock. The local farmers took the livestock emissions as manure; therefore the pollutant export was calculated as $12 \%$ of the emissions generated, according to Technical Outline for Preparation of "National Drinking Water Source Protection Plan" [25]. Thus the loss of COD and $\mathrm{NH}_{3}-\mathrm{N}$ in 2009 was 49,266 and 4,661 tons. Pollutants that enter into the water through the surface runoff pose a serious threat to the water environment of the Nansi Lake Basin.

3.3.3. Aquaculture Pollution. From 2002 to 2012, the development of the aquaculture industry has been gentle, but its pollution to basin water environment could not be ignored. Various acts of aquaculture can be a serious threat to the eutrophication of the basin water environment. For example, the continuous expansion of an aquaculture area, the rich diversity of breeding species, the continuous increasing of bait used from the aquaculture industry, and the emission of aquaculture industry wastewater without any treatment result in the produced pollutants that remain in the water entirely.

The main mode of the aquaculture in the Nansi Lake Basin is the fence breeding and the main breeding species 
of fish. Depending on the "manual on producing pollution coefficient of aquaculture industry," the producing pollution coefficient equals its discharge coefficient [33]. Based on the discharge coefficient of COD $(22.086 \mathrm{~g} / \mathrm{kg})$ and $\mathrm{NH}_{3}-\mathrm{N}$ $(34.047 \mathrm{~g} / \mathrm{kg})$, the amount of aquaculture pollution emissions can be calculated.

In 2009, the aquaculture area of the Nansi Lake Basin reached $735.01 \mathrm{~km}^{2}$ and the annual production of aquatic products was $4.95 \times 10^{5}$ tons. According to the proportion of production and bait $(1: 1.8), 8.90 \times 10^{5}$ tons of bait should be put into the Nansi Lake Basin. Because the bait residues rate of the aquaculture was generally $15 \%$ [25], there were $1.34 \times$ $10^{5}$ tons bait remaining in the water, which released $1.09 \times 10^{4}$ tons COD and $1.68 \times 10^{4}$ tons $\mathrm{NH}_{3}-\mathrm{N}$, respectively, further causing the pollution of the basin water environment.

\section{Strategies Analysis of Nansi Lake Basin Pollution Control in Recent Years}

Basin pollution control is a great challenge worldwide. As a buffer lake of the South-to-North Water Diversion Project (east route), the water pollution of the Nansi Lake Basin must be controlled by the actual situation, taking into consideration the interaction of basin pollution control and economic development. We explore the "TREATMENT, RECYCLING and RESTORATION" system, a fresh basin pollution control strategy, to control pollution comprehensively from sources, process, the basin, and others. In order to achieve a fundamental change of water quality on the Nansi Lake Basin, the participants not only include local legislation and environmental protection, water conservation, and other related departments, but also involve many other industries and thousands of people.

4.1. "TREATMENT, RECYCLING and RESTORATION", a Basin Pollution Control Strategy. In 2002, Nansi Lake was used as a case of the application of the "TREATMENT, RECYCLING and RESTORATION" system. It was explored to complete the work on time for the "South-To-North Water Diversion Project."

Treatment refers to pollution control. This is the application of an integrated process, to ensure that treated wastewater meets the natural environment standard for the growth of common fish. Recycling means wastewater reuse. This means that water reuse and recycle systems must be set, for enterprises and regions in an effort to reduce wastewater discharge into the environment. Restoration means ecological system restores. It is about constructing artificial wetlands and ecological waterways, to form an ecological zone around rivers and lakes, which will enhance basin's environmental capacity to self-defend from pollution.

Compared to pollution management methods undertaken by developed countries, the "TREATMENT, RECYCLING and RESTORATION" method offers reducing the pollution, while increasing environmental capacity. The method effectively releases the pressure caused by basin pollution and gives developing regions the ability to solve their basin pollution problem, while still maintaining a suitable speed of industrialization and urbanization.

\subsection{Fishery Pollution Control Strategy on the Nansi Lake Basin.} As an important buffer lake of the South-to-North Water Diversion Project (east route), water quality of the lake should be better than a Class III of the "China surface water quality standard (GB3838-2002)," according to the "Water Pollution Prevention Planning of the South-to-North Water Diversion Project (east route) of Shandong Section." Therefore, in hopes of fishery pollution control, the Nansi Lake Basin takes a number of measures, for example, planning breeding areas and optimizing breeding structure, developing ecological fishery, and returning the breeding fish of the area to lake.

To improve water quality of lakes and increase the income of fishermen, Jining City formed a multilevel water ecological protection zone. Nutrients in aquatic environment are established by planting the waterweeds and breeding the river snail. Structures of breeding species in the lakes are adjusted to breeding quality economic fishes. Excess nutrients in lakes are transferred by fishing. Studies [22, 34, 35] have shown that each $6.67 \mathrm{~km}^{2}$ of fish products can remove 396 tons of organic matter, 11 tons of nitrogen, and 2 tons of phosphorus and increase economic benefits by more than 5.0 $\times 10^{5}$ yuans. It will not only be able to take full advantage of natural resources and reduce pollution, but also reduce the input of waste and maximize environmental benefits.

According to the "Planning on Functional Zoning and Breeding Control of Nansi Lake's Fisheries," Jining government normally controls the exploitation of Nansi Lake's aquatic ecological resources, delimiting a $66.67 \mathrm{~km}^{2}$ area for perennial closed fishing, a $4,366.67 \mathrm{~km}^{2}$ area for ecological restoration, and a $253.33 \mathrm{~km}^{2}$ area for aquaculture areas, to effectively control fishery pollution on the Nansi Lake Basin. Aquaculture areas include a $66.67 \mathrm{~km}^{2}$ area for ecological crab zone, a $20 \mathrm{~km}^{2}$ area for cage fish with no feeding, and a $166.67 \mathrm{~km}^{2}$ area for ecological breeding in lakeside pond [36]. Simultaneously, based on the "Supervision and Guidance on Pollution Control and Upgrade Work of Nansi Lake's Fisheries," Jining combines fishery production with integrated prevention and control of water environmental pollution, to develop "clarified water fishery" and "ecological fishery." At present, Jining actively carries out the work on clearing feeding cages, and they already have cleared tens of thousands of acres.

\subsection{Agriculture and Animal Husbandry Pollution Control} Strategy on the Nansi Lake Basin. There are large-scale reclaimed lands from the lake and from stockbreeding, as well as a large number of highly polluting industries including paper, mills, and chemical plants within the region. It totals about $253.33 \mathrm{~km}^{2}$ of wetlands destroyed and increases the water environmental pollution load of the Nansi Lake Basin. Wetlands are a natural barrier for pure water. To ensure water quality of the South-to-North Water Diversion Project (east route), the Nansi Lake Basin takes a series of measures on ecological restoration and protection, such as backing land to lakes and returning the area breeding fish to the lake. 
Furthermore, green lines are built around the Nansi Lake for breeding large tracts of wetlands.

From 2005, Jining implemented the "Artificial Wetlands Demonstration Project" in the estuaries of Xinxue River. A total of $43.33 \mathrm{~km}^{2}$ of artificial wetlands and restored original ecological wetlands have achieved remarkable effects. At the time, the project was widely used in the whole Nansi Lake Basin and the area was $120 \mathrm{~km}^{2}$. The farmland nonpoint source pollution system was built in the Nansi Lake Basin to reduce nitrogen and phosphorus in agricultural drainage and nonpoint source pollution which come from the littoral zone. It is easy to find that the water purification capacity of the Nansi Lake Basin wetlands can reach $1.9 \times 10^{5}$ tons per day and the removal rate of COD or N, P is about $50 \%$ or $60 \%$, respectively [22]. This is effective in improving the water quality of the river the flows into the lake and increasing the environmental capacity of the Nansi Lake.

According to the "Scheme on livestock and poultry industry pollution prevention in South-To-North Water Diversion Project," Weishan County took many measures to achieve recycling of waste, reusing of resources, and reducing of livestock and poultry industry pollution, for example, optimizing the layout of large-scale breeding livestock and poultry, constructing sewage treatment projects, carrying out cleaner production, and building the ecological production mode. Moreover, laws and regulations are met to promote pollution prevention and control of the livestock and poultry industry.

In addition, watershed pollution should also be controlled starting at point source pollution and industrial structure, to achieve an aim of solving the water pollution problem on the Nansi Lake Basin. Based on the "TREATMENT, RECYCLING and RESTORATION" pollution control strategy, local environmental standards should be put in place and implemented to gradually remove the privileges of some highly polluting industries to discharge waste. At the same time, local government should put these companies under tremendous pressure to adjust and optimize their industrial structure. Enterprises should be required to carry out cleaner production and take effectual measures to control pollution within a deadline. On the other hand, there is an increasing number of sewage treatment plant to solve environmental problems caused by direct sewage discharge. Heavy polluters should be required to build biological health indication ponds for discharging points to ensure that common fish can live in the treated wastewater.

\section{Conclusions and Suggestions}

Through analyzing variation trends of the water environmental quality with total GDP increasing in the Nansi Lake Basin in the past decade, it is easy to find that the concentrations of $\mathrm{COD}$ and $\mathrm{COD}_{\mathrm{Mn}}$ have decreased year by year, despite the double-digit GDP annual growth, and the average annual descent rate was, respectively, 7.69\% and 6.69\%. Compared with 2002, the overall downward rate of COD and $\mathrm{COD}_{\mathrm{Mn}}$ was $84.59 \%$ and $74.69 \%$. The water environmental quality of the Nansi Lake Basin has been improved greatly, basically reaching a Class III water standards, and the main polluted rivers in the basin have restored the growth of common fish. In 2013, a project of the eastern route of the South-ToNorth Water Diversion Project was achieved, marking that the toughest pollution management issues of the Nansi Lake Basin have been overcome.

Based on analysis of industry structure and pollutants discharge, it is found that nonpoint source pollution and point source pollution such as industrial sewage and domestic sewage caused the water quality deterioration of the Nansi Lake Basin. And nonpoint source pollution is the primary pollution source, accounting for the proportion of about $85 \%$. Furthermore, nonpoint source pollution of agricultural fertilizers and pesticides accounted for over $90 \%$, followed by the pollution of livestock and aquaculture.

Nonpoint source pollution brings $\mathrm{COD}, \mathrm{NH}_{3}-\mathrm{N}$ into the basin water environment through the form of underground seepage and surface flow runoff, which pose a threat to water environment of the Nansi Lake Basin. In 2009, the pollution of $\mathrm{COD}$ and $\mathrm{NH}_{3}-\mathrm{N}$ caused by agricultural fertilizers and pesticide, respectively, accounted for $91.68 \%$ and $86.05 \%$. The loss of $\mathrm{COD}$ and $\mathrm{NH}_{3}-\mathrm{N}$ continued to increase with the enlargement of the breeding scale and area, in which COD loss of livestock and poultry breeding reached $4.90 \times 10^{4}$ tons. Moreover, $\mathrm{NH}_{3}-\mathrm{N}$ pollution of the water environment was mainly caused by aquaculture, with the loss of $1.70 \times 10^{4}$ tons.

For current water environmental pollution situation of the Nansi Lake Basin, the "TREATMENT, RECYCLING and RESTORATION" basin pollution control strategy should be implemented by two aspects gradually: point source and nonpoint source. And industrial structure should be modified to optimize the industrial proportion. The pollution of primary industry should be treated comprehensively in three aspects: source, process, and extremity. For example, ecological fishery must be developed so that nutrition can progress through the food chain and reduce bait input. On the other hand, surface and subsurface flow artificial wetlands should be constructed in many key areas to enhance the self-purification capacity of the eco-system. In addition, animal husbandry should be planned reasonably for farming range and strengthening the ecological development cycle with agriculture. All these efforts are expected to improve scientifically and rationally the water environmental capacity of the Nansi Lake Basin.

\section{Conflict of Interests}

The authors declare that there is no conflict of interests regarding the publication of this paper.

\section{Acknowledgments}

The authors would like to thank Jameson Kwan for polishing the language of the paper. This work was financially supported by the Project of Shandong Province Environmental Protection Bureau (no. SDHBPJ-ZB-09) and China National Key Program for Water Pollution Control (no. 2009ZX07210007). 


\section{References}

[1] M. O. Ribaudo, "Regional estimates of off-site damages from soil erosion," in The Off-Site Costs of Soil Erosion. Proceedings of a Symposium Held May 1985, T. E. Waddell, Ed., p. 284, Conservation Foundation, Washington, DC, USA, 1986, Soil \& Water Conservation, vol. 40, pp. 9-13, 1986.

[2] State Environment Protection Administration of China, Report on the State of the Environment of China, China Environment Science Press, Beijing, China, 2000, (Chinese).

[3] United States Environmental Protection Agency (USEPA), "National management measures for the control of non-point pollution from agriculture," Tech. Rep. EPA-841-B-03-004, Environmental Protection Agency, Office of Water, Washington, DC, USA, 2003.

[4] B. C. Braskerud, "Factors affecting nitrogen retention in small constructed wetlands treating agricultural non-point source pollution," Ecological Engineering, vol. 18, no. 3, pp. 351-370, 2002.

[5] E. D. Ongley, Z. Xiaolan, and Y. Tao, "Current status of agricultural and rural non-point source Pollution assessment in China," Environmental Pollution, vol. 158, no. 5, pp. 1159-1168, 2010.

[6] H. Bu, W. Meng, and Y. Zhang, "Nitrogen pollution and source identification in the Haicheng River basin in Northeast China," Science of the Total Environment, vol. 409, no. 18, pp. 3394-3402, 2011.

[7] H. Yu, B. Xi, J. Jiang, M. J. Heaphy, H. Wang, and D. Li, "Environmental heterogeneity analysis, assessment of trophic state and source identification in Chaohu Lake, China," Environmental Science and Pollution Research, vol. 18, no. 8, pp. 1333-1342, 2011.

[8] H. Y. Guo, X. R. Wang, and J. G. Zhu, "Quantification and index of non-point source pollution in Taihu Lake region with GIS," Environmental Geochemistry and Health, vol. 26, no. 2, pp. 147156, 2004.

[9] X. Wang, W. Zhang, Y. Huang, and S. Li, "Modeling and simulation of point-non-point source effluent trading in Taihu Lake area: perspective of non-point sources control in China," Science of the Total Environment, vol. 325, no. 1-3, pp. 39-50, 2004.

[10] Z. Shen, Q. Liao, Q. Hong, and Y. Gong, "An overview of research on agricultural non-point source pollution modelling in China," Separation and Purification Technology, vol. 84, pp. 104-111, 2012.

[11] J. Ma, Z. Ding, G. Wei, H. Zhao, and T. Huang, "Sources of water pollution and evolution of water quality in the Wuwei basin of Shiyang river, Northwest China," Journal of Environmental Management, vol. 90, no. 2, pp. 1168-1177, 2009.

[12] B. Sun, L. Zhang, L. Yang, F. Zhang, D. Norse, and Z. Zhu, "Agricultural non-point source pollution in China: causes and mitigation measures," Ambio, vol. 41, no. 4, pp. 370-379, 2012.

[13] United States General Accounting Office (USGAO), "Water pollution: greater EPA leadership needed to reduce nonpoint source pollution," Tech. Rep. RCED-91.10, US Government Accounting Office, Gaithersburg, Md, USA, 1990.

[14] G. T. Miller, Living in the Environment: An Introduction to Environmental Science, Wadsworth Publishing, Belmont, Tenn, USA, 7th edition, 1992.

[15] M. J. Bowes, J. Hilton, G. P. Irons, and D. D. Hornby, “The relative contribution of sewage and diffuse phosphorus sources in the River Avon catchment, southern England: implications for nutrient management," Science of the Total Environment, vol. 344 , no. 1-3, pp. 67-81, 2005.

[16] M. Stuart, D. Lapworth, E. Crane, and A. Hart, "Review of risk from potential emerging contaminants in UK groundwater," Science of the Total Environment, vol. 416, pp. 1-21, 2012.

[17] X. Ma, Y. Li, M. Zhang, F. Zheng, and S. Du, "Assessment and analysis of non-point source nitrogen and phosphorus loads in the Three Gorges Reservoir Area of Hubei Province, China," Science of the Total Environment, vol. 412-413, pp. 154-161, 2011.

[18] A. Taebi and R. L. Droste, "Pollution loads in urban runoff and sanitary wastewater," Science of the Total Environment, vol. 327, no. 1-3, pp. 175-184, 2004.

[19] W. Guo, Y. Fu, B. Ruan, H. Ge, and N. Zhao, "Agricultural nonpoint source pollution in the Yongding River Basin," Ecological Indicators, vol. 36, pp. 254-261, 2014.

[20] DB37/599-2006, Discharge standard of water pollutants for the route of South-to-North Water Diversion Project in Shandong Province, 2006.

[21] W. C. An and X. M. Li, "Phosphate adsorption characteristics at the sediment-water interface and phosphorus fractions in Nansi Lake, China, and its main inflow rivers," Environmental Monitoring and Assessment, vol. 148, no. 1-4, pp. 173-184, 2009.

[22] L. X. Zhang, S. Ulgiati, Z. F. Yang, and B. Chen, "Emergy evaluation and economic analysis of three wetland fish farming systems in Nansi Lake area, China," Journal of Environmental Management, vol. 92, no. 3, pp. 683-694, 2011.

[23] H. Jia, Y. Z. Yan, J. M. Lü et al., "Countermeasure on ecological environmental protection in Nansi Lake," Yunnan Environmental Science, vol. 24, pp. 66-69, 2005.

[24] M. Aqeel Ashraf, M. Jamil Maah, and I. Yusoff, "Water quality characterization of Varsity Lake, University of Malaya, Kuala Lumpur, Malaysia," Journal of Chemistry, vol. 7, supplement 1, pp. S245-S254, 2010.

[25] Chinese Research Academy of Environmental Sciences, Technical Outline for Preparation of "National Drinking Water Source Protection Plan", Chinese Research Academy of Environmental Sciences, 2006.

[26] GB18596-2001, Discharge standard of pollutants for livestock and poultry breeding, 2001.

[27] X. Z. Gao, T. Shen, and Y. Zheng, Practical Handbook of Fertilizer, China Agriculture Press, Beijing, China, 2002.

[28] W. Ouyang, A. K. Skidmore, A. G. Toxopeus, and F. Hao, "Longterm vegetation landscape pattern with non-point source nutrient pollution in upper stream of Yellow River basin," Journal of Hydrology, vol. 389, no. 3-4, pp. 373-380, 2010.

[29] S. Li and J. Li, "Research progress on losses of fertilizer nitrogen," Agro-Environmental Protection, vol. 20, pp. 377-379, 2001.

[30] Q. Xu, "A review on the status of non-point source pollution of chemical fertilizers and pesticides in China," Rural EcoEnvironment, vol. 12, pp. 39-43, 1996.

[31] S. W. Yoon, S. W. Chung, D. G. Oh, and J. W. Lee, "Monitoring of non-point source pollutants load from a mixed forest land use," Journal of Environmental Sciences, vol. 22, no. 6, pp. 801-805, 2010.

[32] L. Pei-Yue, Q. Hui, and W. Jian-Hua, "Groundwater quality assessment based on improved water quality index in Pengyang County, Ningxia, Northwest China," E-Journal of Chemistry, vol. 7, no. 1, pp. S209-S216, 2010.

[33] Manual of producing pollution coefficient for aquaculture industry, China Pollution Source Census, 2010. 
[34] S. Manasi, "Water pollution impacts on livelihoods: a case study of fishing communities in Tungabhadra Sub Basin," in Knowledge Systems of Societies for Adaptation and Mitigation of Impacts of Climate Change, Environmental Science and Engineering, pp. 347-365, Springer, Berlin, Germany, 2013.

[35] M. S. Islam and M. Tanaka, "Impacts of pollution on coastal and marine ecosystems including coastal and marine fisheries and approach for management: a review and synthesis," Marine Pollution Bulletin, vol. 48, no. 7-8, pp. 624-649, 2004.

[36] Planning on Functional Zoning and Breeding Control of Nansi Lake's Fisheries, Jining, 2012, http://www.jining.gov.cn/art/2012/ 2/24/art_183_80175.html. 

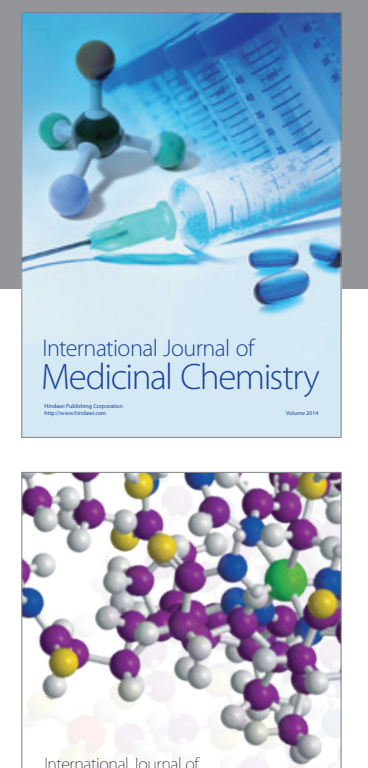

\section{Carbohydrate} Chemistry

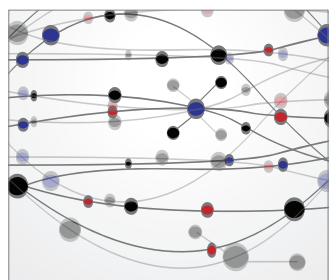

The Scientific World Journal
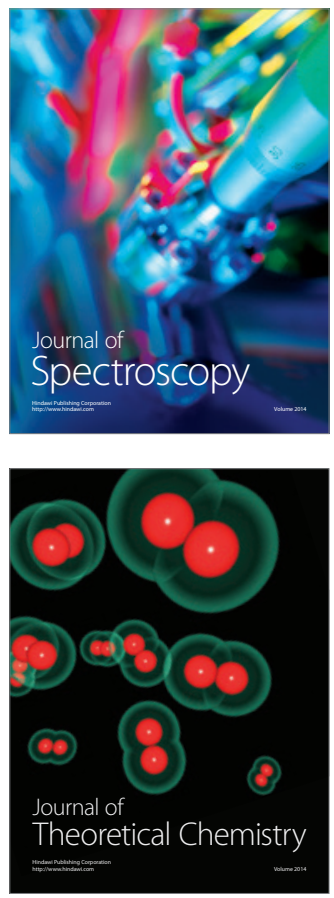
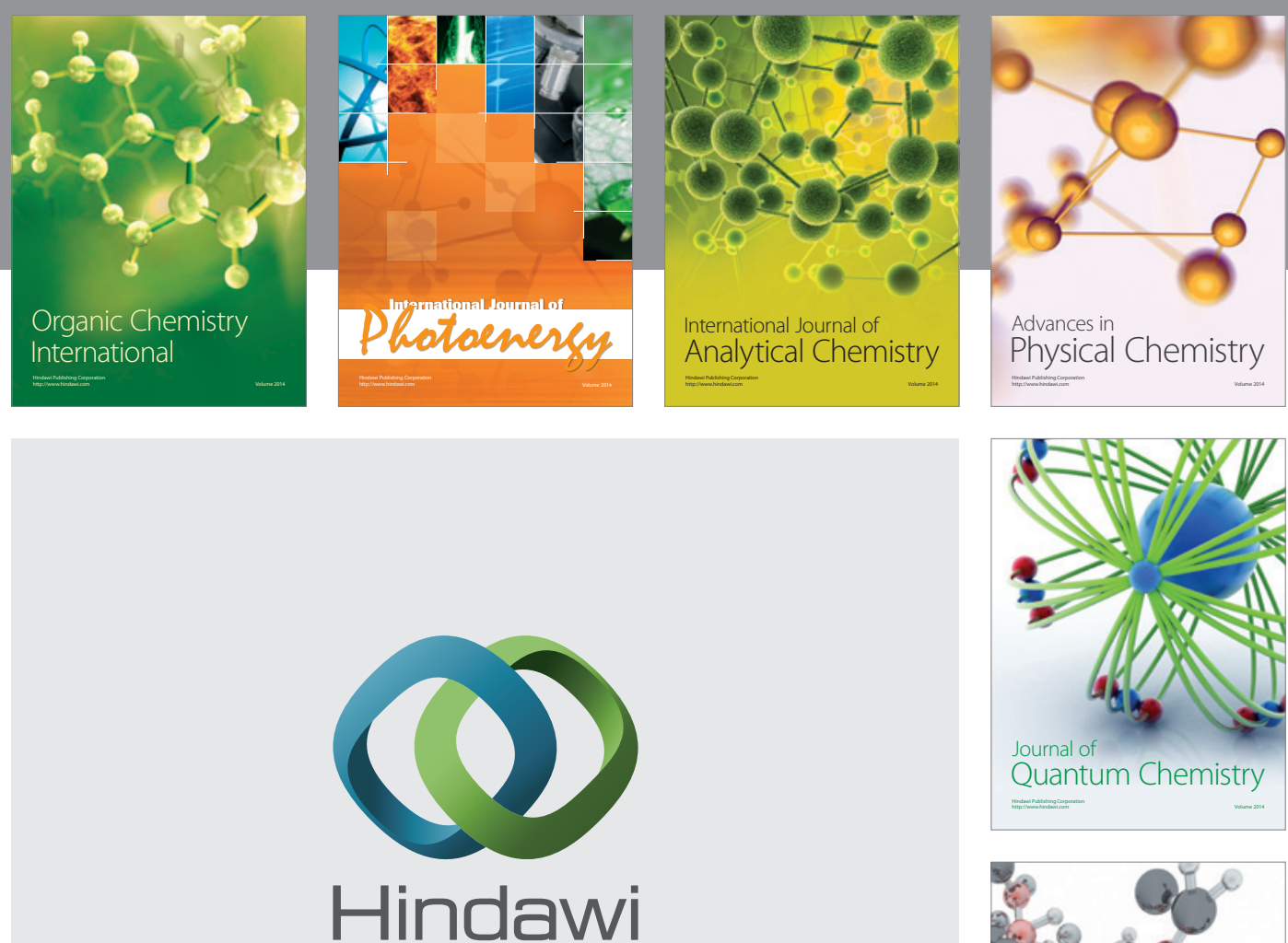

Submit your manuscripts at

http://www.hindawi.com

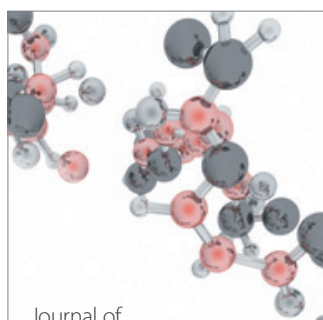

Analytical Methods

in Chemistry

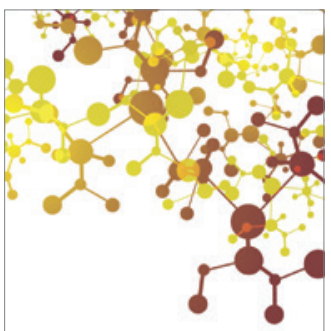

Journal of

Applied Chemistry

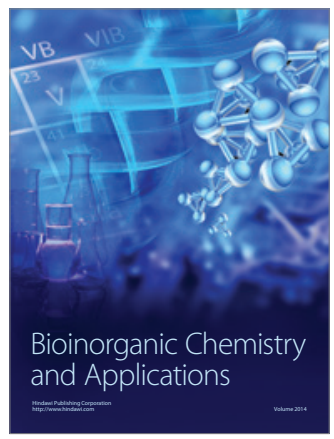

Inorganic Chemistry
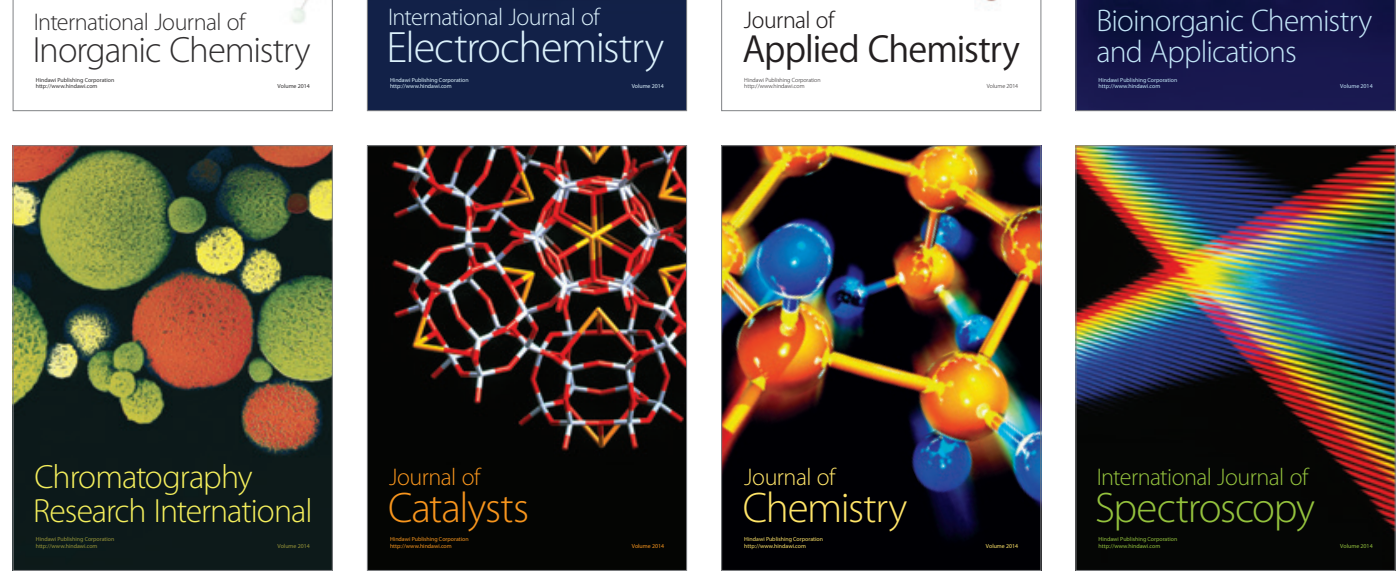